\title{
RESULTS OF SOCIOLOGICAL STUDY OF ECONOMIC FACTORS OF EFFECTIVENESS OF VICTIMOLOGICAL PREVENTION OF SECURITY OF LIVING ENVIRONMENT
}

\author{
Volodymyr Shablystyi ${ }^{1}$, Vitaliy Prymachenko
}

\begin{abstract}
One of the criminological science dogmas is that prophylaxis and prevention of offenses are made at three levels: general social (in society as a whole), special (in relation to certain types (groups) of offenses) and individual (with a specific offender). Some scientists allocate the fourth level of prophylaxis and prevention of an offense into regional or sectoral ones. Some scholars call these levels somewhat differently, but their content is approximately the same, and, most importantly, they all aim to create a sense of security of each of us from violations of norms of laws, morals, traditions, etc. Of course, the scientific provision of crime prevention is impossible without a proper economic basis. The complexity of such studies is that since the end of 2013 and till now the development of Ukraine was marked by the acute problem of ensuring security in the full sense of the word and the leveling of the single person's safety. We hope that making a sociological study of the economic factors of the effectiveness of victimological prevention of the living environment from a human position may be a part of the general return to the state development vector of a person with its rights, freedoms and responsibilities.
\end{abstract}

Key words: economic support, victimological prevention, human security, crime, state of security.

JEL Classification: F52, H56

\section{Introduction}

The history of human development shows the multifaceted and ambiguous nature of civilization processes in different social entities at different times. In fact, by the end of the twentieth century, each country tried to preserve its achievements in clearly defined borders with all available means. The ideas of the Renaissance, which were not progressive in time, were reflected in the legislative acts only at the end of the twentieth century - at the beginning of the XXI century. It is a vital need, inherent in each of us aspiration from birth: to live in safety. Moreover, for this purpose, selfish manifestations have always been and will be defined, these are personal, safety of relatives. Of course, without the security of society and state, one can hardly speak of an individual's safety. At the same time, only now everybody seriously started talking about the correctness and the long-overdue need for the normative-legal consolidation of the transformation of the triad of the most important values "state-societyhuman" to the diametrically opposite one - "humansociety-state".

Ever since the renaissance of the Axiom, the crime rate can be reduced in two ways: by minimizing the causes of criminal behavior and by enhancing criminal

Corresponding author:

${ }^{1}$ Dnipropetrovsk State University of Internal Affairs, Ukraine.

E-mail: vo-1 shablisty@ukr.net

${ }^{2}$ Dnipropetrovsk State University of Internal Affairs, Ukraine.

E-mail: primachenko_vf@email.ua repression. It is much easier to eliminate the cause than to deal with the aftermath. Crime cannot be defeated or eradicated, it can only be reduced by a few indicators to a socially tolerant or better socially acceptable level (Schmalleger, 2005).

In view of this, it becomes apparent that there is a need to find or qualitatively upgrade the existing means of influencing those who commit or are likely to commit various offenses. One of such means of influence should be setting on preventive account of offenders or persons who are inclined to commit certain offenses, carrying out with them real individual preventive work; victimology prevention; government programming against crime, including through planning for the safety of the living environment (Yurtayeva, Hladkova, Shcherbakova, 2018).

This should ensure the proper logistical support of law enforcement and minimize the potential for abuse, as it is a temporary restriction on the rights and freedoms of the individual and citizen. The preventive accounting of persons who are inclined to commit certain types of offenses should be restricted in the public domain, as otherwise the achievement of their purpose becomes an impossible task. Planning for home security is impossible without taking into account the views of all stakeholders. 


\section{2. "State-society-human"} or "human-society-state"

There is an axiomatic statement that scientific research firstly in humanities should be made in the standpoint of a person, not a society or a state, since the country at the highest level having proclaimed a human as the highest social value should contribute to the continuous progressive development of science, in order to implement its results in legislation, in the practice of its application and in further research elaboration subsequently. At the same time not every country in the basis of its political activity can put interests of the man, and not of the state. In this area only developed countries have succeeded, first of all Scandinavian, because human security is a very costly problem in terms of its ensuring. That is why security is very often a problem for the very person who is forced to spend his/her own resources to provide it.

Human security is freedom without fear and freedom without poverty. This is a necessary condition for the development of a person, who is the goal of cooperation for development. The purpose of development is to provide people with the opportunity to live a long life and to be healthy (health), to continuously acquire new knowledge (education) and to have access to resources to ensure a decent living standard (material well-being). If human development is aimed to empowerment, then the human security concept is looking for ways to avoid, mitigate and cope with threats (Dopovid OON Pro rozvytok lyudstva).

The term "human security" has been used internationally since the publication by the United Nations Development Program (UNDP) in 1993 of the "Human Development Report" in which the concept of human security refers to people, not to states and nations, with this limited concept of national security expands more generally: the safety of man or humanity. The safety of all people, not just the state or the nation, must be in the first place, it must be ensured not by force structures, but through human development. After that, each UN member state annually reports on the safety of its people every year with clearly defined parameters (Dopovid OON Pro rozvytok lyudstva).

Ukraine belongs to those states where public interest prevails over private in all fields of social development. Opened since the seizure of Ukrainian seamen in the Sea of Azov, the Russian military aggression against the entire civilized world has forced most of the gross domestic product to spend on the security of the state, i.e. the army. In such a situation, the solution to the problem of personal security of every Ukrainian, his/her everyday habitual way of life, is assigned to him-/herselves. Of course, it is about the economic factors of victimological prevention of the security of the living environment.

The victimological prevention itself should be understood as a system of interrelated, organizationally secured state, social and individual measures aimed at identifying and eliminating or neutralizing factors that form a person's or a mass opportunity to become a victim of a crime (Atlas bezpeky lyudyny).

We share the assertion that in any field of study a central figure, the main subject of responsibility is a person. Without him/her there cannot exist any other subject of social relations, of which is nothing more than a manifestation of the self-organization of man (people) in a civilized society (Hryshchuk, 2012).

In March-November 2018, in order to develop effective measures of victimological prevention of human safety, a sociological study aimed at studying citizens' opinion on the crime prevention through the planning of territories and the security of the living environment has been conducted.

\section{Results and discussion}

Object of the research is the citizens' opinion on matters of crime prevention through planning territories, and security of living environment. The purpose of the study is to find out the citizens' opinion on crime prevention through planning territories, the security of the living environment. The objectives of the study:

1) to find out citizens' opinion regarding the state of the house they live in;

2 ) to find out citizens' opinion regarding the lighting of their home and adjoining territory;

3) to determine citizens' security level in their area, in their district / neighborhood, in their courtyard;

4) to identify causes of anxiety and sense of security of citizens in their settlements, districts, yards;

5) to find out the level of protection from criminals and encroachments on life, health and property;

6) to find out the respondents' opinion regarding the increase in the number of crimes in courtyards and entrances;

7) to find out the respondents' opinion regarding the authorities' activities of their settlement to ensure the citizens' safety;

8) to determine citizens' opinion regarding causes of committing crimes near their houses or in houses themselves (entrances);

9) to identify the basic measures necessary to improve the living environment security.

Hypotheses of the study:

Direct 1. Most respondents are satisfied with condition of their home.

Reverse 1. Most respondents are not satisfied with condition of their home.

Direct 2. Respondents assess the lighting level of their homes and adjoining areas satisfactorily.

Reverse 2. Respondents, on the contrary, indicate that the lighting of their homes and the adjoining areas are unsatisfactory.

Direct 3. Most citizens say they are safe enough in their area, in their neighborhood / in the courtyard. 
Reverse 3. Respondents indicate that they are at risk in their area, district / neighborhood, yard.

Direct 4. Most respondents feel anxiety through street crime.

Reverse 4. On the contrary, the vast majority of respondents feel safe.

Direct 5. Respondents feel protected from crimes and encroachments on life, health, property.

Reverse 5. Respondents say they do not feel protected from crime and from attacks on life, health and property.

Direct 6. Respondents believe that in recent years the number of crimes in courtyards and entrances has increased.

Reverse 6. On the contrary, the vast majority of respondents believe that in recent years the number of crimes in courtyards and entrances has decreased.

Direct 7. Respondents in most cases believe that the authorities of their settlements are making every effort to ensure the citizens' safety.

Reverse 7. Respondents believe that the authorities of their locality do not make enough efforts to ensure the citizens' safety.

Direct 8. Most respondents believe that the main reasons for committing crimes near houses or in houses (entrances) themselves are the passivity of building residents and government bodies.

Reverse 8. Most respondents tend to think that the reasons for committing crimes near houses or in homes (entrances) are the lack of lighting in yards, streets.

Direct 9. Citizens believe that the main measures necessary to improve the security of the living environment are the involvement of public authorities and police in the planning of residential areas, and landscaping.
Reverse 9. Respondents argue that the main measures necessary to improve the security of the living environment are the incentives for building owners and apartment owners in multistoried buildings to make improvements and order in the territory.

\section{Methodical part}

Method and sample. The study was held using a continuous survey. A total of 1001 respondents were interviewed. Toolkit: The questionnaire consisted of 24 questions: 16 were of closed type, where respondents had to choose one answer from the proposed options; 8 were of semi-closed type, where, along with the proposed variants of the answer, the respondent's own answer variant was foreseen.

\section{Findings}

Thus, we have found out that the improvement of education will lead to a reduction in the level of crime and an increase in the culture of both group and individuals, and this will become a solid foundation for human security. The problem of security is the problem of each of us; its solution requires material costs, including our own. The government and civil society institutions should be more actively involved in solving problems of an individual citizen from lighting of the entrance to the house to introducing new approaches to the work of law enforcement agencies. Each problem is individual.

In general, one of the most important criteria for the progressive development of the system, increase

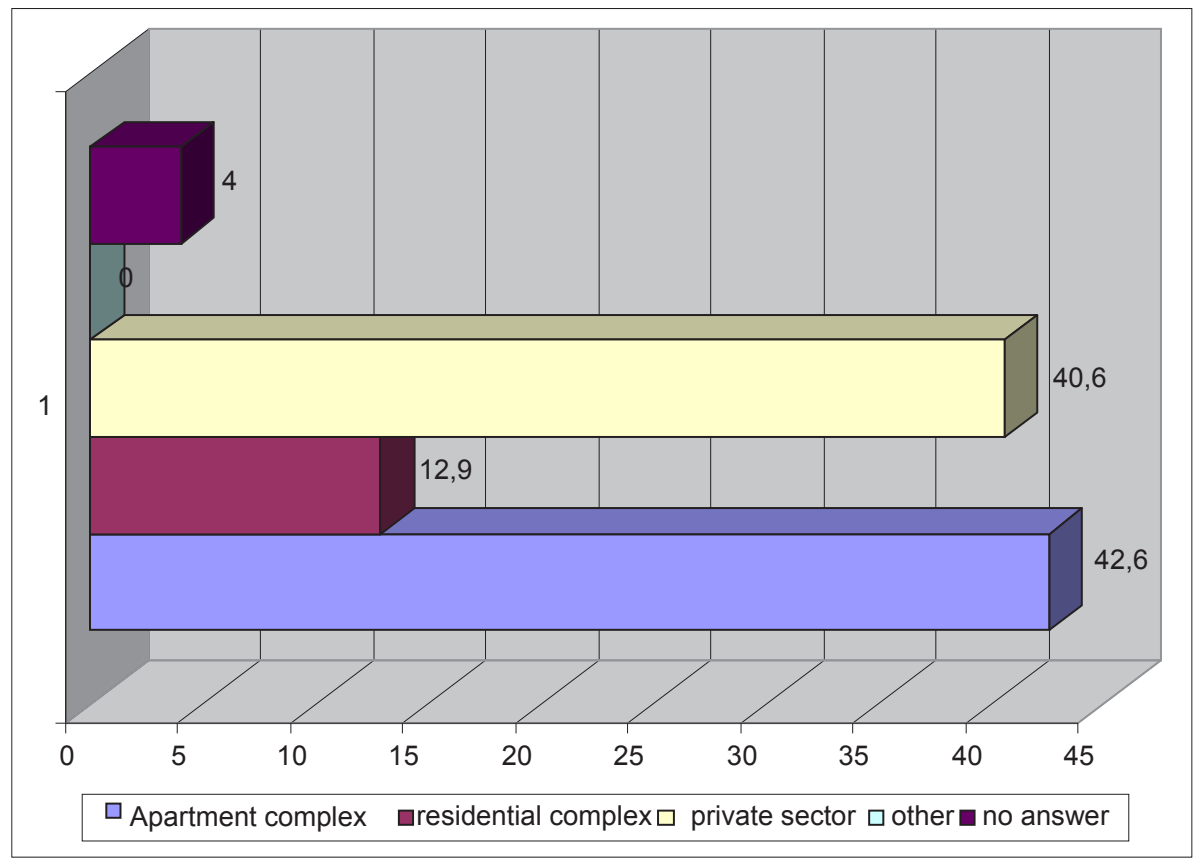

Figure 1. Distribution of answers to the question "You live in ...", \% 


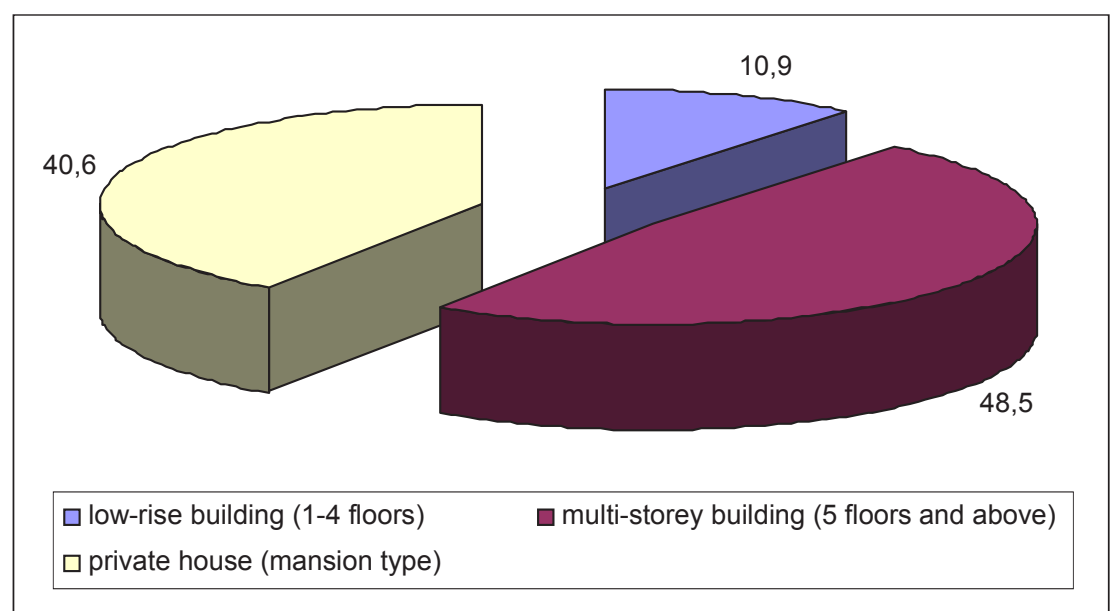

Figure 2. Distribution of answers to the question "What house do you live in?", \%

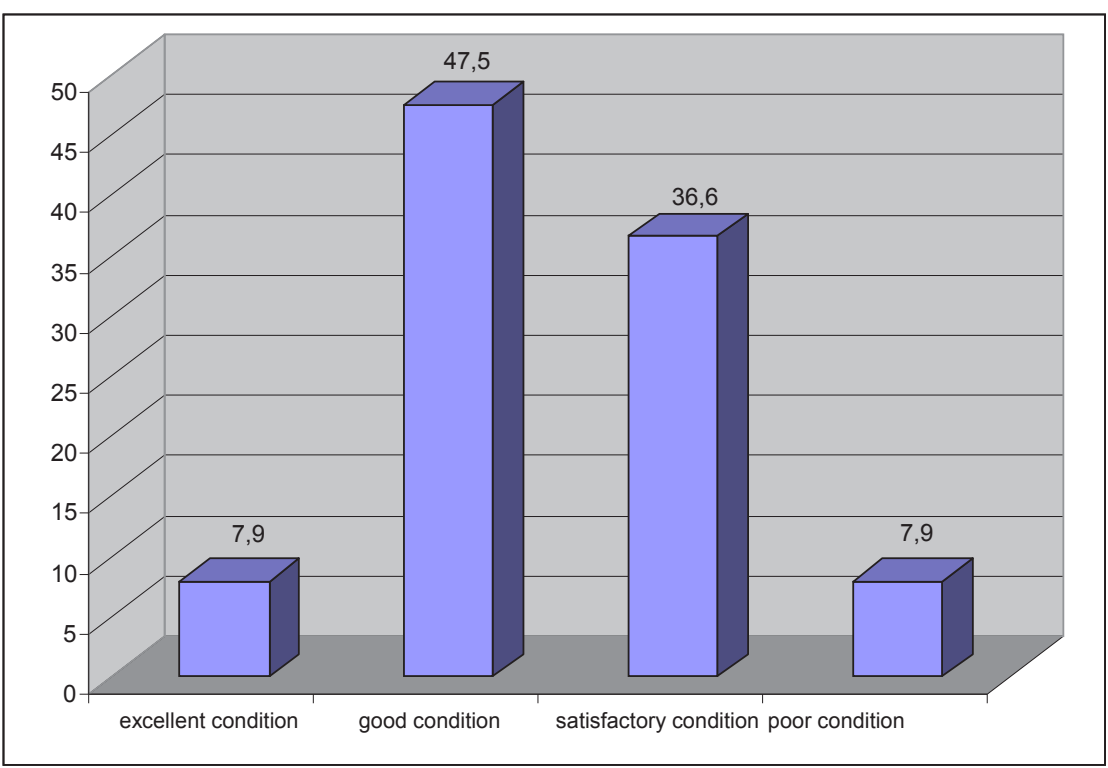

Figure 3. Distribution of answers to the question "What condition is your home in?", \%

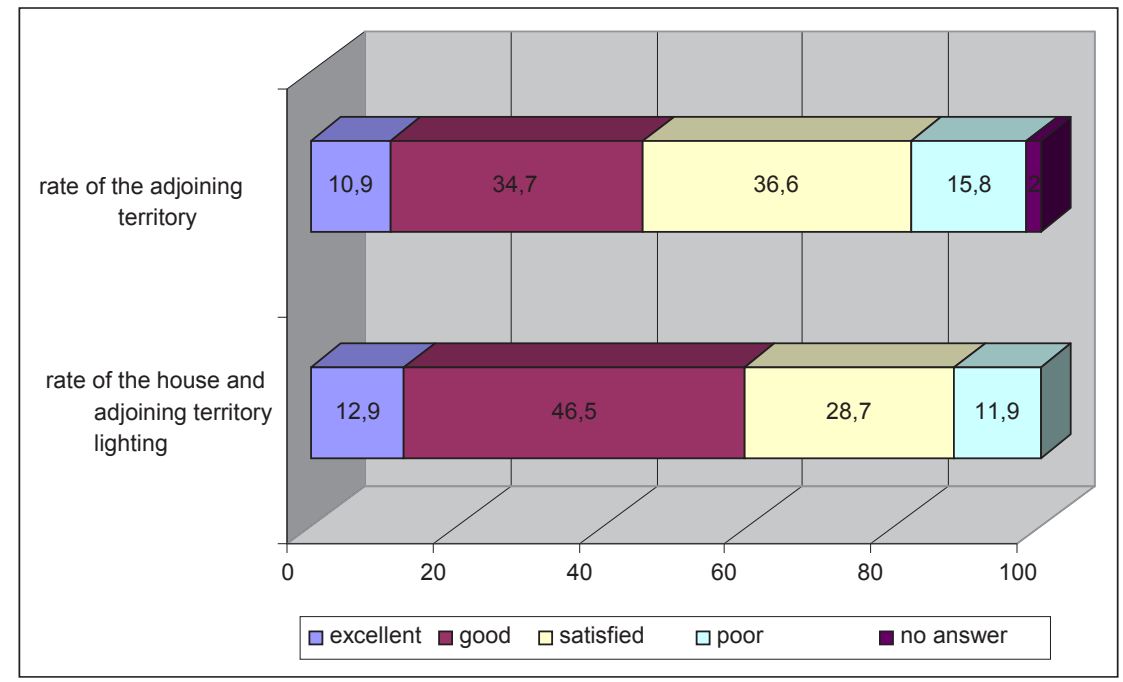

Figure 4. Distribution of answers to the question "How do you assess the lighting rate of a building and the rate of the adjoining territory?", \% 


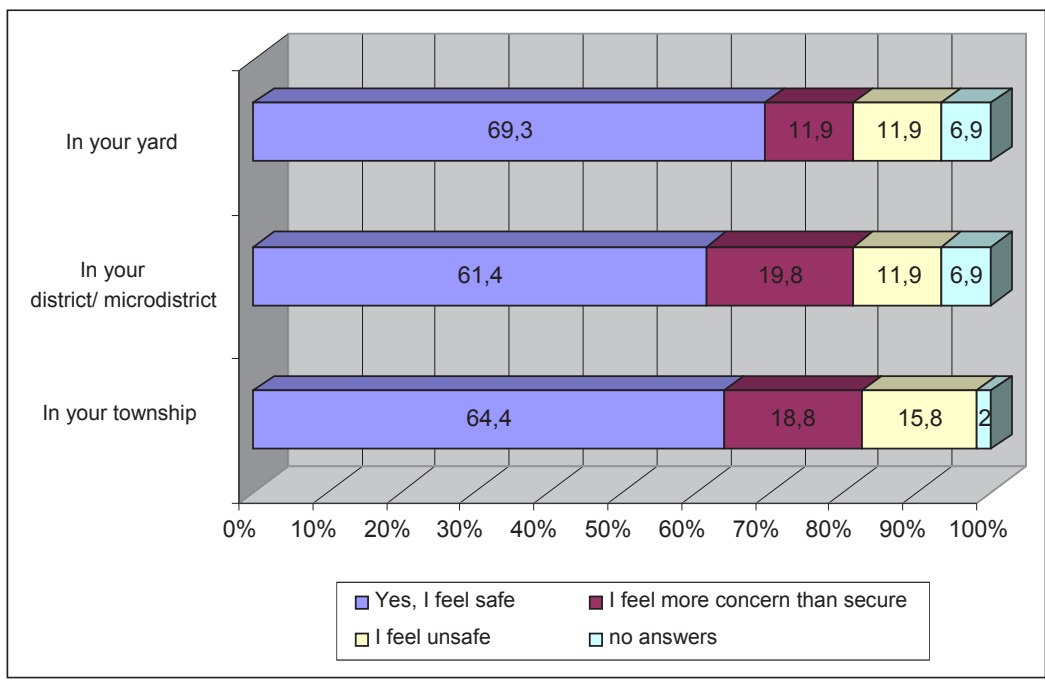

Figure 5. Distribution of answers to the question "Do you feel safe?", \%

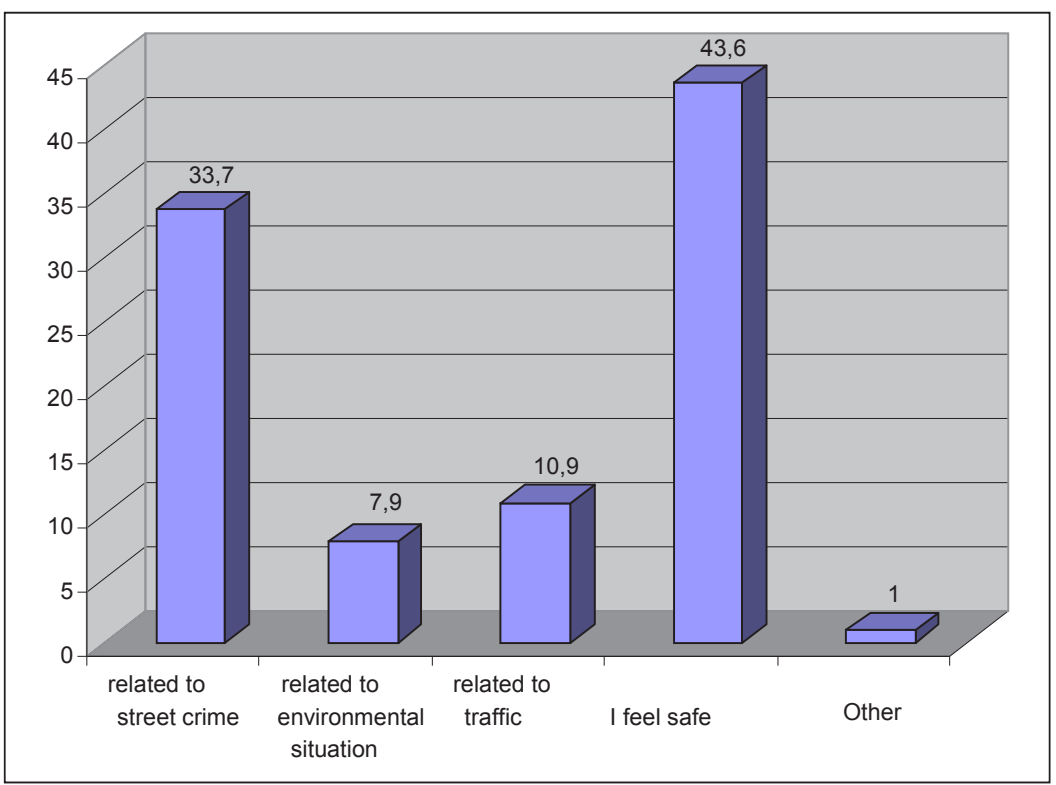

Figure 6. Distribution of answers to the question

"If you feel anxious or do not feel safe, then why", \%

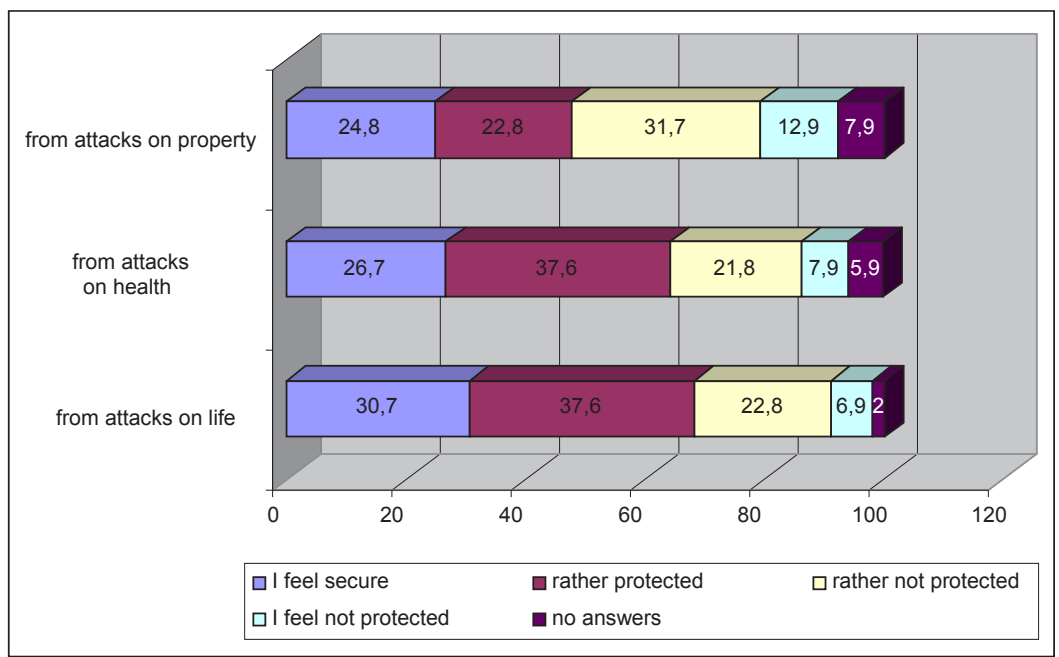

Figure 7. Distribution of answers to the question

"Do you feel protected from criminals, from encroachments?", \% 


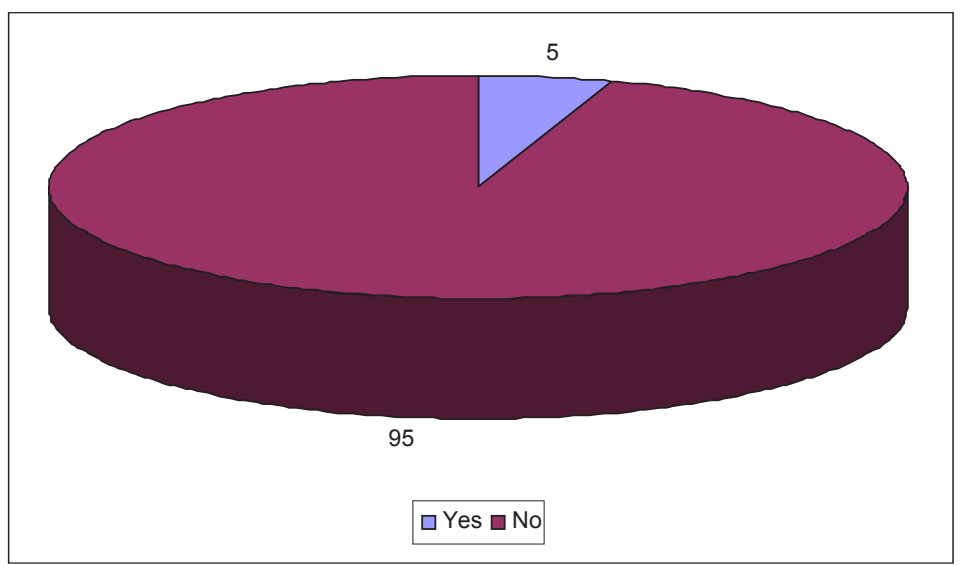

Figure 8. Distribution of answers to the question

"Have you personally become a victim of crime over the past two years?", \%

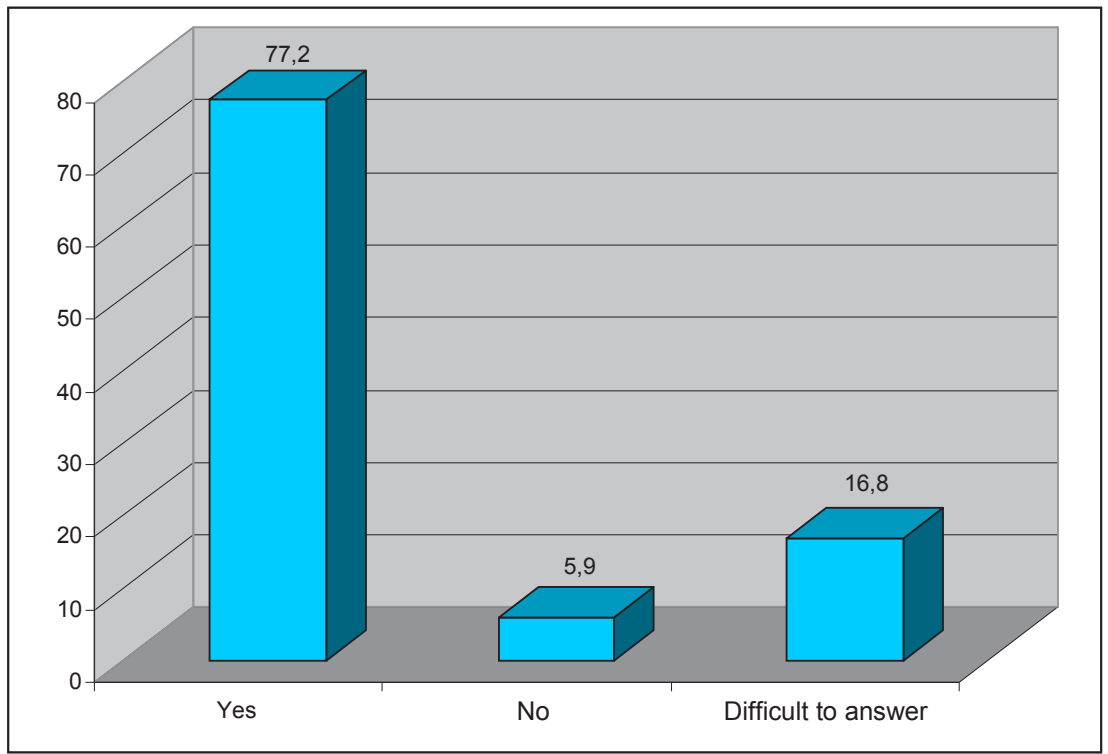

Figure 9. Distribution of answers to the question "Has the number of crimes committed in courtyards and entrances increased in recent years?", \%

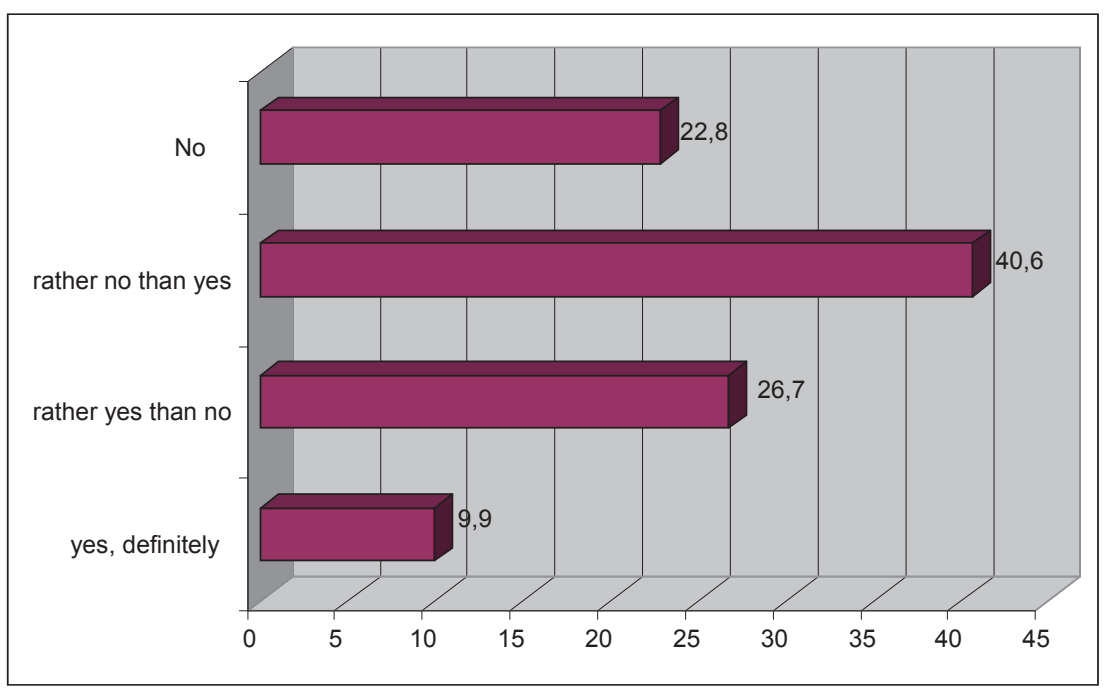

Figure 10. Distribution of answers to the question "Do you think that the authorities of the locality where you live do their best to ensure the citizens safety?", \% 


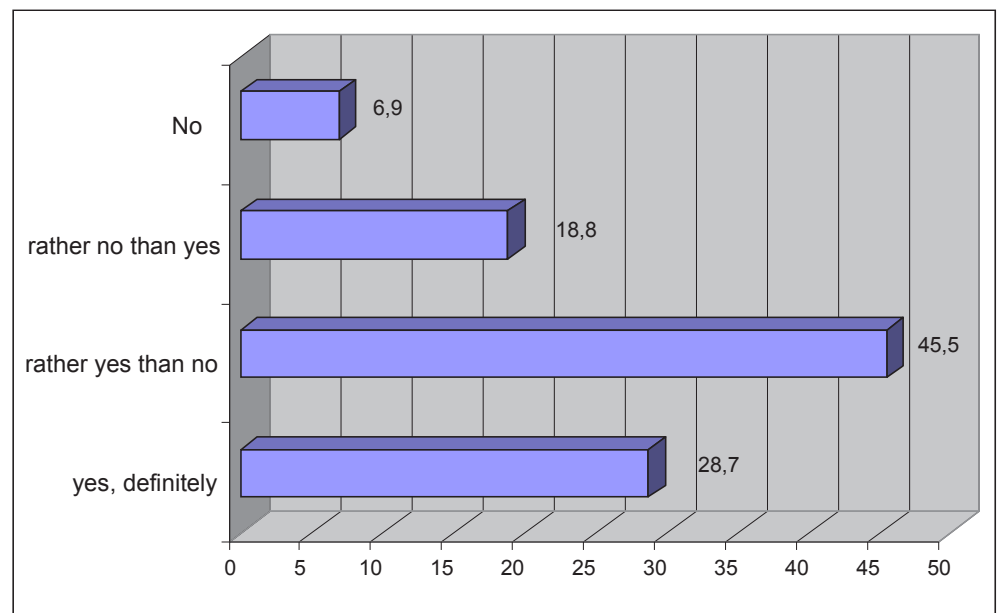

Figure 11. Distribution of answers to the question "In your opinion, do signs of mess and homelessness in streets and houses courtyards awaken in people the unconscious desire to break the peace, do a mess, hooligan acts?", \%

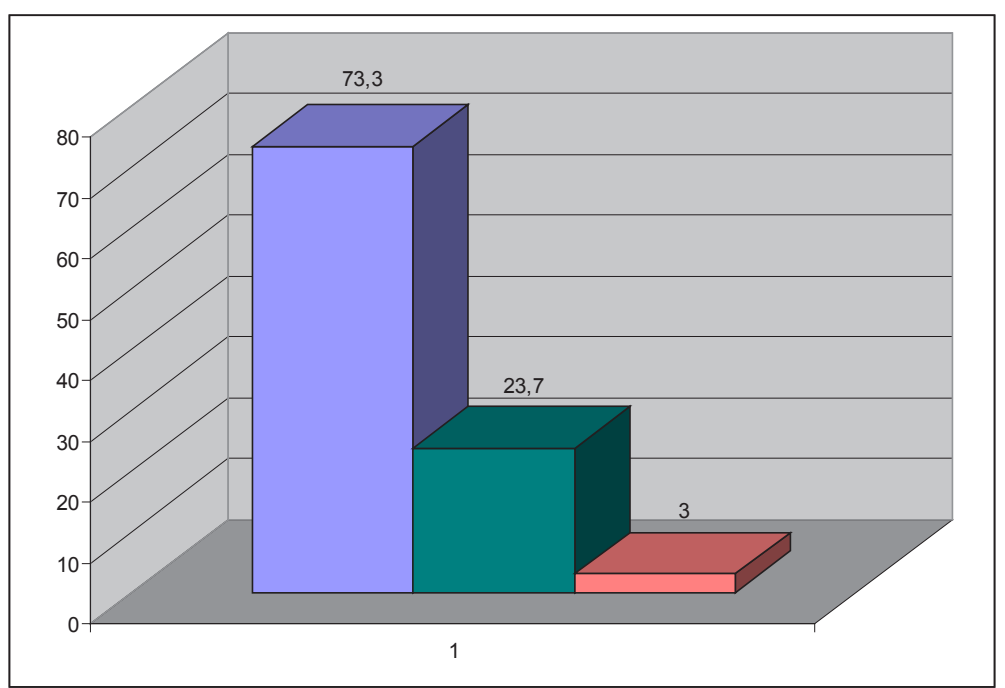

Figure 12. Distribution of answers to the question

"Do you participate in cleaning and landscaping at your home?", \%

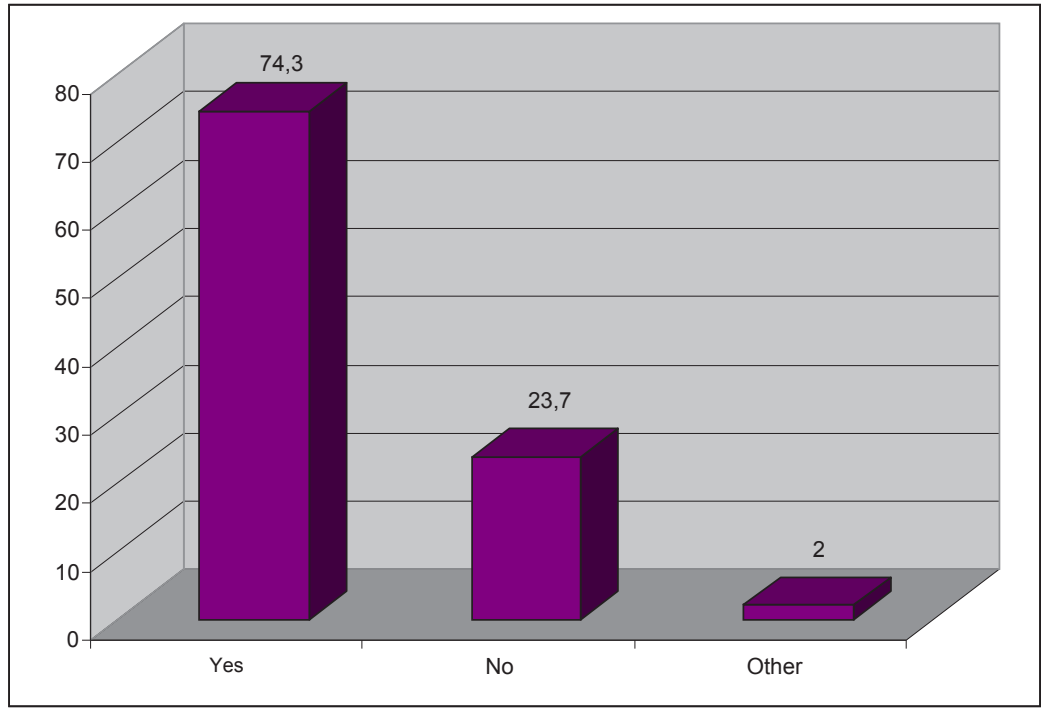

Figure 13. The answers to the question "Is it appropriate to legislatively oblige building and apartments owners in apartment buildings to clean and participate in the landscaping of the adjoining territory to the house?", \% 
its level of organization (and, consequently, the decrease of entropy) is the differentiation, complexity of the structure, the diversity of the components of the elements system. Law of the necessary variety of U.R. Ashby also works in the social world. This is well understood by foreign researchers, in particular A. Toffler, an active supporter of raising the level of social diversity. It is particularly important to emphasize now that a new thinking is needed to form it, to liberate it from dogmatic shades, and to captivate stereotypes of barracks of equality, general unanimity and unanimous thinking, for decades cultivated in the USSR "syndrome of uniformity" (Hylynskyy, 2013).

\section{Conclusions}

Among the respondents are the youngest people of 26-35 years old. It should be noted that respondents over 45 were not questioned.

As for the distribution of gender, the vast majority of respondents are males: $86.1 \%$.

The largest number of inhabitants is of cities $64.4 \%$, the smallest number is on;y $8.9 \%$ of residents of settlements.

The number of inhabitants of both microdistricts and the private sector is almost identical, $42.6 \%$ and $40.6 \%$ respectively.

Most of respondents were residents of multistoried (48.5\%) and private (40.6\%) houses.

The condition of their homes was estimated by the majority of respondents as good $-47.5 \%$, satisfactory $36.6 \%$, equal answers on the criteria of excellent and poor - by $7.9 \%$.

The rate of lighting of their houses and the territory of the neighborhood is estimated by the respondents as good $(46.5 \%)$, and the state of the adjoining territory is estimated mostly satisfactorily $(36.6 \%)$ and well (34.7\%).

The respondents mostly feel safe in their own area, district and yard. They feel safest in their yard (69.3\%), the most dangerous in their township (15.8\%).

The main reason for anxiety and feeling of danger is related to street crime, $33.7 \%$ of respondents say this.

Respondents mostly feel protected from attacks on life and health. The most vulnerable respondents feel from attacks on property $-44.6 \%$.

Almost all respondents (95.0\%) during the last two years personally did not become victims of a crime.

The majority of respondents (77.2\%) believe that in recent years the number of crimes committed in courtyards and entrances has increased.
Respondents tend to believe that the authorities of the locality where they live do not do their best to ensure the safety of citizens (63.4\%).

The vast majority of respondents (74.2\%) believe that the signs of disorder and homelessness in the streets and courtyards of houses awaken in the people the unconscious desire to break the peace, do a mess, commit hooligan acts.

According to the respondents, among the main reasons for committing crimes near houses or in the houses themselves (entrances), there is, first of all, the lack of lighting in the yards, streets; passivity of inhabitants of houses; lack of control and neglect of the building territory, the presence of abandoned buildings; passivity of state authorities.

In order to improve the security of living environment, the following measures are necessary: installation of video surveillance systems; involvement of state authorities and police in planning of residential areas, landscaping; increasing the transparency of territories and reducing the number of passes, abandoned buildings, unlit places; participation of citizens in patrolling the territory to ensure the necessary level of law and order; stimulation of buildings and apartments owners in multi-apartment buildings for improvement and ordering in the territory.

The majority of respondents (73.3\%) take part in cleaning and improvement of the territory near their houses.

The same number of respondents does not tend to think that the more families are owners of the adjoining territory, the more unattended it looks.

$74.3 \%$ of respondents consider that it is expedient to oblige houses and apartment owners in multistory buildings at the legislative level to clean and to take part in the landscaping the adjoining territory.

Consequently, the results of a sociological study of the economic factors of the effectiveness of victimological prevention of the living environment security in Ukraine proved that the population asserts their own security and the security of the living environment on the government or other social entities, especially not willing to take part personally. Ensuring human security in all spheres depends on the country's economic development, investment in security is the future of investment, and therefore further research on this issue should be carried out in order to scientifically substantiate the feasibility of allocating funds from the local and state budgets for the victimological safety of the living environment.

\section{References:}

Schmalleger, F. (2005). Criminal justice today: an introductory text for 21st century. 8th ed. p. cm. Includes bibliographical references and index. 1. Criminal justice, Administration of United States I. Title.

Yurtayeva, K., Hladkova, Ye., \& Shcherbakova, A. (2018). Role of mass media in combating drug-related crime. Baltic Journal of Economic Studies, vol. 4, no. 3, pp. 366-371. doi: 10.30525/2256-0742/2018-4-3-366-371 
Dopovid OON Pro rozvytok lyudstva [The report UN About development of the people]. Retrieved from: http://hdr.undp.org/en/media/HDR_2011_RU_Complete.pdf (in Ukrainian)

Atlas bezpeky lyudyny [Atlas of human security]. Retrieved from: http://lapas.lv/ru/безопасность-чемовека/ (in Ukrainian)

3. Dzhuzha, O. M., Kondratyev, Ya. Yu., Kulyk, O. H., Mykhaylenko, P. P. and other (2002). Kryminolohiya: pidruchnyk dlya studentiv vyshchykh navch. zakladiv. [Criminology]. Kyiv: Yurinkom Inter. (in Ukrainian)

Hryshchuk, V. K. (2012). Filosofs'ko-pravove rozuminnya vidpovidalnosti lyudyny: monohrafiya [Hilosophical and legal understanding of human responsibility]. Khmel'nytskyy: Khmelnytskyy universytet upravlinnya ta prava. (in Ukrainian)

Hylynskyy, Ya. Y. (2013). Sotsyalnoe nasylye: monohrafyya [Social Violence]. Sankt-Peterburg: OOO Izdatel'skyy Dom «Alfa Press». (in Russian) 